\title{
ADAPTATION - BASE OF PROTECTION OF PLANT ORGANISM FROM THE INFLUENCE OF HEAVY METALS
}

\author{
Dovgopola Kateryna*, Garkava Kateryna, Bruzgina Tetyana
}

National Aviation University, Kyiv, Ukraine

\section{АДАПТАЦІЯ - ОСНОВА ЗАХИСТУ РОСЛИННОГО ОРГАНІЗМУ ВІД ВПЛИВУ ВАЖКИХ МЕТАЛІВ}

\author{
Довгопола Катерина, Гаркава Катерина, Брюзгіна Тетяна \\ Received 26. 6. 2017 \\ Revised 28. 6. 2017 \\ Published 27.11.2017
}

The study of the adaptation of medicinal plants in the area near the aerodrome to determine the degree of penetration of soil to heavy metals was a purpose of our investigations. It was established of level of biological resistance of plants to pollution for environmental monitoring of the environment. The soil samples and medicinal plants were collected on the territory adjacent to the Zhulyany airfield in the Kyiv region and the aerodrome in Nizhyn, Chernihiv region. To study, the roots of Taraxacum officinale W. and Cichorium intybus L. have been isolated. These parts of plants are used in official medicine for phytopreparations, therefore analysis of the content of heavy metals in them is relevant. In the soil, the content of heavy metals $(\mathrm{Cd}, \mathrm{Zn}, \mathrm{Pb}, \mathrm{Cu})$ was determined using $\mathrm{HCl}(1 \mathrm{~N})$, in plants $-\mathrm{HNO}_{3}(1: 1)$ by atomic absorption spectrophotometer $\mathrm{C}-115$. To estimate soil contamination, the coefficient of the technogenic concentration was used. The coefficient of biological absorption is used to determine the intensity of migration of heavy metals from the soil to plants. The analysis of the lipid composition in medicinal plant samples was carried out by gas-liquid chromatography. It is established that in soil the content of heavy metals doesn't exceed the maximum permissible concentrations. Heavy metals according to the intensity of accumulation by plants have the following order: $\mathrm{Cd}>\mathrm{Cu}>\mathrm{Zn}>\mathrm{Pb}$. The property of the investigated plants for the accumulation of heavy metals can be used as one of the methods of phytoremediation and phytomonitoring of the medium. Investigation of the content of fatty acids in the plant material may indicate the reaction of the plant organism to stress and as a consequence of further study of the process of adaptation of the plant to the state of growth. The conditions of germination have an effect on the biochemical parameters of biologically active substances in Taraxacum officinale and Cichorium intybus. It has been established that Cichorium intybus is more resistant to unfavorable conditions of germination.

Keywords: adaptation; soil; heavy metals; lipids; herbs

\section{Вступ}

Дикорослі трав'янисті рослини являють собою цінний природний ресурс, який відіграє важливу роль у функціонуванні природних екосистем і $\epsilon$ джерелом рослинної харчової і лікарської сировини. Враховуючи, що на природні екосистеми велике навантаження

*Corresponding author: Kateryna Dovgopola, National Aviation University, Kyiv, Ukraine, 
має промисловість і транспорт, рослини постійно відчувають на собі вплив безлічі різних стресових факторів.

Серед полютантів, які в значних кількостях викидаються в навколишнє середовище і можуть накопичуватися рослинами, особливо виділяється група важких металів, тому ресурсні дослідження і заготовки рослинної сировини повинні супроводжуватися хімічним аналізом на забруднюючі речовини.

Реакції рослин на хімічні стреси, викликані надлишком або нестачею мікроелементів, не можна розглядати як константу, адже у рослин в ході еволюції і протягом індивідуального життя виробляються механізми, що приводять до адаптації і нечутливості до зміни і порушення хімічного балансу в навколишньому середовищі (Овчаренко, 1997). Тому реакції рослин на важкі метали в ґрунті повинні досліджуватися в системи «ґрунтовий субстрат - рослина».

Дослідження адаптації рослин, що зростають на території поблизу аеродромів надає можливість з'ясувати рівень надходження через ґрунт до рослин важких металів і рівень біологічної стійкості рослин до забруднення.

\section{Матеріали та методи}

Метою нашої роботи було дослідження рівня накопичення важких металів в ґрунті та рослинах: кульбаби лікарської (Taraxacum officinale W.) і цикорію дикого (Cichorium intybus L.) і встановити вплив умов проростання на жирнокислотний склад ліпідів.

Лікарські рослини збирали на території, прилеглій до аеродрому “Жуляни" Київської області та Ніжинського аеродрому Чернігівської області. Для контролю були взяті аптечні фітопрепарати рослин.

Рослини збирали з дотриманням вимог збирання та підготовки рослинної сировини встановлених в фармакогнозії (Ковальов та ін., 2004; Кобзар, 2007) і методик відбору проб грунту і рослин (Методические указания..., 1992).

Для дослідження були відібрані окремі частини рослин: корені кульбаби лікарської і цикорію дикого. Саме ці частини рослин використовуються в офіційній медицині з метою отримання фітопрепаратів, тому аналіз вмісту в них важких металів $\epsilon$ актуальним.

Вміст важких металів ( $\mathrm{Cd}, \mathrm{Zn}, \mathrm{Pb}, \mathrm{Cu})$ у ґрунті визначали з використанням 1н HCl, в рослинах $\mathrm{HNO}_{3}(1: 1)$ на атомно-абсорбційному спектрофотометрі С-115 (Методические указания..., 1992). Для оцінки забрудненості ґрунтів було використано коефіцієнт техногенної концентрації Кс (характеризує відношення реального вмісту хімічного елемента в ґрунті С до фонового вмісту цього ж елемента С в середовищі: Кс = Са/С $\phi)$. Величина Кс свідчить про активність процесів вилуговування (Кс < 1) і накопичення (Кс > 1) хімічних елементів у ґрунті (Петрук та ін., 2013).

Для визначення інтенсивності міграції важких металів з ґрунту в рослини використано коефіцієнт біологічного поглинання Кбп (відношення вмісту елемента 1х у золі рослини до $\mathrm{nx}-$ вмісту елемента у ґрунті: Кбп = 1x/nx) (Перельман и Касимов, 1999).

Аналіз жирнокислотного складу ліпідів в зразках лікарських рослин проводився методом газорідинної хроматографії (Брюзгіна та ін., 2013).

\section{Результати та їх обговорення}

Отримані дані дослідження за результатами аналізу вмісту важких металів в зразках ґрунту та лікарських рослин представлені в таблицях 1 - 3.

Проведені дослідження виявили, що на обстежених ділянках вміст полютантів не перевищує гранично-допустимі концентрації. Внаслідок розрахунку Кс виявлено, що цей показник для Cu, Zn i Cd не перевищує одиницю і коливається в межах 0,12 - 0,68, тобто ці елементи вилуговуються із ґрунту. Лише для $\mathrm{Pb} \mathrm{Kc}>1$, а одже відбувається процес його накопичення. 
Таблиця 1 Аналіз вмісту важких металів в зразках ґрунту

Table 1 The analysis of heavy metals in soil samples

\begin{tabular}{|c|c|c|c|c|c|c|c|c|}
\hline \multirow{2}{*}{$\begin{array}{l}\text { Місце відбору проб } \\
\text { ґрунту }\end{array}$} & \multicolumn{2}{|c|}{$\mathrm{Cu}$} & \multicolumn{2}{|c|}{$\mathrm{Zn}$} & \multicolumn{2}{|c|}{$\mathbf{P b}$} & \multicolumn{2}{|c|}{$\mathrm{Cd}$} \\
\hline & $\mathrm{Mr} / \mathrm{Kr}$ & Kc & $\mathbf{M r} / \mathbf{K r}$ & Kc & $\mathrm{Mr} / \mathrm{Kr}$ & Kc & $\mathrm{Mr} / \mathrm{Kr}$ & Kc \\
\hline Київ “Жуляни” & 5,37 & 0,26 & 12,8 & 0,26 & 12,68 & 1,27 & 0,34 & 0,68 \\
\hline Ніжин САЗ & 2,4 & 0,12 & 19,46 & 0,4 & 12,7 & 1,3 & 0,17 & 0,34 \\
\hline Фоновий вміст & 20 & - & 50 & - & 10 & - & 0,5 & - \\
\hline гдк & 55 & - & 100 & - & 32 & - & 3 & - \\
\hline
\end{tabular}

Таблиця 2 Вміст міді та цинку в зразках лікарських рослин

Table 2 The content of copper and zinc in samples of medicinal plants

\begin{tabular}{|c|c|c|c|c|c|c|c|c|}
\hline \multirow{3}{*}{$\begin{array}{l}\text { Місце відбору } \\
\text { зразків }\end{array}$} & \multicolumn{4}{|c|}{ Taraxacum officinale } & \multicolumn{4}{|c|}{ Cichorium intybus } \\
\hline & \multicolumn{2}{|c|}{ мідь, мг/кг } & \multicolumn{2}{|c|}{ цинк, мг/кг } & \multicolumn{2}{|c|}{ мідь, мг/кг } & \multicolumn{2}{|c|}{ цинк, мг/кг } \\
\hline & $1 x$ & Кбп & $1 x$ & Кбп & $1 x$ & кбп & $1 x$ & Кбп \\
\hline Київ “Жуляни” & $9,93 \pm 0,9$ & 1,85 & $30,20 \pm 2,0$ & 2,4 & $14,27 \pm 0,8$ & 2,7 & $33,50 \pm 2,0$ & 2,7 \\
\hline Ніжин САЗ & $6,57 \pm 0,6$ & 2,74 & $22,49 \pm 1,7$ & 1,6 & $11,43 \pm 0,5$ & 4,8 & $31,11 \pm 1,8$ & 1,6 \\
\hline Фітопрепарат & $10,52 \pm 1,0$ & - & $15,9 \pm 1,2$ & - & $12,9 \pm 0,2$ & - & $29,4 \pm 1,5$ & - \\
\hline гдк & 5,0 & - & 10,0 & - & 5,0 & - & 10,0 & - \\
\hline
\end{tabular}

Таблиця 3 Вміст свинцю та кадмію в зразках лікарських рослин

Table 3 The content of lead and cadmium in samples of medicinal plants

\begin{tabular}{|c|c|c|c|c|c|c|c|c|}
\hline \multirow{3}{*}{$\begin{array}{l}\text { Місце відбору } \\
\text { зразків }\end{array}$} & \multicolumn{4}{|c|}{ Taraxacum officinale } & \multicolumn{4}{|c|}{ Cichorium intybus } \\
\hline & \multicolumn{2}{|c|}{ свинець, мг/кг } & \multicolumn{2}{|c|}{ кадмій, мг/кг } & \multicolumn{2}{|c|}{ свинець, мг/кг } & \multicolumn{2}{|c|}{ кадмій, мг/кг } \\
\hline & $1 x$ & Кбп & $1 x$ & Кбп & $1 x$ & Кбп & $1 x$ & Кбп \\
\hline Київ “Жуляни” & $0,98 \pm 0,2$ & 0,07 & $0,64 \pm 1,8$ & 1,9 & $4,82 \pm 0,2$ & 0,4 & $2,01 \pm 0,04$ & 6 \\
\hline Ніжин САЗ & $0,62 \pm 0,03$ & 0,05 & $0,17 \pm 0,02$ & 1 & $1,03 \pm 0,4$ & 0,08 & $0,25 \pm 0,03$ & 1,4 \\
\hline Фітопрепарат & $1,82 \pm 0,1$ & - & $0,27 \pm 0,03$ & - & $1,15 \pm 0,2$ & - & $0,39 \pm 0,03$ & - \\
\hline гдк & 0,5 & - & 0,03 & - & 0,5 & - & 0,03 & - \\
\hline
\end{tabular}

Результати досліджень показали, що вміст важких металів у рослинній сировині перевищує гранично-допустимі концентрації, це свідчить про високий рівень акумуляції іонів металів. Згідно з даними Кбп інтенсивність накопичення металів рослинами в середньому можна розташувати у такому порядку КбпCd > KбпCu >. KбпZn > KбпPb.

Для того, щоб вивчити адаптаційний потенціал, зокрема рослинного організму, потрібно знати, якою $є$ реакція організму на відхилення того чи іншого фактора від норми, які механізми сприяють пристосуванню до мінливих умов середовища.

Велику роль у процесі адаптації до дії антропогенного навантаження, в тому числі до підвищеного вмісту важких металів, відіграють біологічно активні сполуки первинного обміну 
(Георгиевский, 1990). Зміни умов середовища відображаються на кількісних показниках біологічно активних речовин, зокрема ліпідів. Ліпіди $\epsilon$ одним з головних компонентів біологічних мембран, які взаємодіють із середовищем.

Дослідження жирнокислотного складу ліпідів дає можливість оцінити вплив умов зростання на рослини і може бути використаним як один із показників екологічного моніторингу території та адаптогенної спроможності організму.

Таблиця 4 Жирнокислотний склад ліпідів в зразках лікарських рослин, \%

Table 4 Fatty acid composition of lipids in samples of medicinal plants, \%

\begin{tabular}{|c|c|c|c|c|c|c|}
\hline \multirow[t]{3}{*}{ Кислота } & \multicolumn{3}{|c|}{ Taraxacum officinale } & \multicolumn{3}{|c|}{ Cichorium intybus } \\
\hline & \multicolumn{3}{|c|}{ місце відбору зразків } & \multicolumn{3}{|c|}{ місце відбору зразків } \\
\hline & Київ “Жуляни” & Ніжин САЗ & Фітопрепарат & Київ “Жуляни” & Ніжин САЗ & Фітопрепарат \\
\hline C14:0 & 3,9 & $6,9^{*}$ & 2,9 & 7,3 & 6,8 & 5,7 \\
\hline C15:0 & 1,9 & 2,8 & 1,4 & 4,4 & 2,9 & 3,4 \\
\hline C16:0 & 40,8 & 41,7 & 40,8 & $44,1^{*}$ & 39,8 & 39,7 \\
\hline C17:0 & 0,9 & 1,4 & 03,7 & 1,5 & 1,9 & 1,1 \\
\hline C18:0 & 4,8 & $6,9^{*}$ & 4,4 & 5,9 & 4,8 & 2,3 \\
\hline C18:1 & $34,9^{*}$ & $30,6^{*}$ & 37,9 & $26,5^{*}$ & $31,2^{*}$ & 36,5 \\
\hline C18:2 & 11,56 & $8,3^{*}$ & 10,9 & 8,8 & 11,6 & 10,2 \\
\hline C18:3 & 1,2 & 1,4 & 1,0 & 1,5 & 1,0 & 1,1 \\
\hline$\Sigma$ нЖк & 52,3 & $59,7^{*}$ & 50,2 & $63,2^{*}$ & $56,2^{*}$ & 52,2 \\
\hline$\Sigma$ НнЖК & 47,7 & 40,3 & 4,98 & $36,8^{*}$ & 43,8 & 47,8 \\
\hline$\Sigma$ пнжк & 12,8 & $9,7^{*}$ & 11,9 & 10,3 & 12,6 & 11,3 \\
\hline
\end{tabular}

* вірогідна різниця з контролем

Згідно з даними таблиці 4, жирнокислотний склад ліпідів кульбаби лікарської має зміни тільки для умов біля Ніжинського аеродрому, так має місце зростання вмісту міристинової ЖК в 2 рази, стеаринової ЖК на 57 \%, та зниження вмісту олеїнової ЖК на 20 \% і лінолевої ЖК на $24 \%$, що обумовлює зростання суми насичених ЖК на 19 \% на фоні зниження суми ПНЖК на 19 \%. Таким чином, умови зростання впливають на біохімічні параметри біологічно активних речовин для кульбаби лікарської, можливо це спричинено процесом адаптації рослин до умов урбанізованого середовища.

Згідно з отриманими результатами умови зростання впливають на жирнокислотний склад ліпідів цикорію дикого і відрізняються від аптечної проби зміною вмісту пальмітинової ЖК, а також зниженням олеїнової ЖК на 15 і 27 \% відповідно, що обумовлює зростання суми насичених ЖК на 8 і 21 \% відповідно. Проведені дослідження свідчать про те, що цикорій більш витривалий до несприятливих умов зростання.

\section{Висновки}

В ґрунті вміст важких металів не перевищує гранично допустимих концентрацій. Важкі метали за інтенсивністю накопичення рослинами розташовуються в наступному порядку: $\mathrm{K} б п \mathrm{Cd}>\mathrm{K} \sigma п \mathrm{Cu}>\mathrm{K} \sigma п \mathrm{Zn}>\mathrm{Kб} \mathrm{Pb}$. Властивість досліджених рослин акумулювати важкі 
метали може бути використана як один із методів фіторемідіації та фітомоніторингу середовища.

Дослідження вмісту насичених та ненасичених жирних кислот в рослинній сировині може свідчити про реакцію рослинного організму на стрес і як наслідок необхідності подальшого вивчення процесу адаптації рослини до умови місця зростання.

Аналіз механізмів адаптації певних видів лікарських рослин, що зростають на урбанізованій території надає можливість з'ясувати рівень надходження через ґрунт до рослин важких металів, рівень біологічної стійкості рослин до забруднення. Тому в подальших дослідженнях буде проводитись робота з вивчення якісних та кількісних зв'язків інших біологічно активних сполук з адаптогенними властивостями рослин.

\section{Література}

Брюзгіна, Т.С., Гаркава, К.Г., Довгопола, К.А. 2013. Спосіб визначення жирнокислотного складу ліпідів кульбаби та цикорію. Патент 82299 Україна, MПК G01N 33/00. №201302230; заявл. 22.02.2013; опубл. 25.07.2013. Бюл., № 14. 4 с.

Георгиевский, В.П. 1990. Биологически активные вещества лекарственных растений. Новосибирск: Наука. 333 с. ISBN: 5-02-029240-0.

Кобзар, А.Я. 2007. Фармакогнозія в медицині: Навч. посіб. К.: Медицина. 544 с. ISBN 966-8326-44-X. $67.50 \mathrm{p}$.

Ковальов, В.М., Павлій, О.І., Ісакова, Т.І. 2004. Фармакогнозія з основами біохімії рослин. Підруч для студ вищ формац навч закл та формач фр-тів вищих мед навч закл III-IV рівнів акред (2-е вид). Х Вид-во НФаУ, МТК-книга. 704 с. ISBN 966-96114-9-0.

Методические указания по определению тяжелых металлов в почвах сельхозугодий и продукции растениеводства. Изд. 2-е, перераб. и доп. Москва. 61 с.

Овчаренко, М.М. 1997. Тяжелые металлы: в системе почва-растение-удобрение. Издательство : М.: «Пролетарский светоч». 290 с. ISBN 5889340166.

Перельман, А.И., Касимов, Г.Н. 1999. Геохимия ландшафтов. М.: «Астрея». 768 с. ISBN 5-7594-0077-0.

Петрук, В.Г.,Васильківський,І.В.,Іщенко, В.А.,Петрук,Р.В.,Турчик,П.М.2013.Нормуванняантропогенного навантаження на навколишнє середовище. Частина 1. Нормування інгредієнтного забруднення: навчальний посібник. Вінниця : ВНТУ. 253 с. 